\title{
Terapia antidepresiboaren azken pausoak: oraina eta geroa
}

\author{
The latest steps in antidepressant treatment: present and future \\ Ines Erkizia-Santamaría ${ }^{1}$, Jorge E. Ortega ${ }^{1,2,3}$, Igor Horrillo ${ }^{1,2}$ \\ ${ }^{1}$ Euskal Herriko Unibertsitatea, Farmakologia Saila. Leioa, Bizkaia \\ ${ }^{2}$ Centro de Investigación Biomédica en Red de Salud Mental CIBERSAM \\ ${ }^{3}$ Biocruces Bizkaia \\ ines.erkizia@ehu.eus
}

\section{Laburpena}

Depresioa gaixotasun psikiatriko ohikoenen artean dago, eta haren intzidentziaren gorakada etengabea da. Depresioaren jatorria eta mekanismo etiologikoak azaltzen dituzten hainbat teoria garatu diren arren, gaixotasunaren oinarri neurobiologikoaren alderdi asko ezezagunak dira oraindik. Hipotesi esanguratsuenak depresioaren teoria monoaminergikoa, neurotrofikoa eta neuroinflamatorioa dira, eta horien eta beste batzuen jatorria, ebidentziak eta xehetasunak aditzera ematen dira berrikuspen honetan. Iraganean depresioa tratatzeko farmakoen aurkikuntza zorizkoa izan da, eta haien ekintza-mekanismoen ikerketak gaixotasunean ageri diren nahasmendu neurobiologikoei buruzko ezagutza eman digu. Azken hamarkadetan, aldiz, paradigma aldatu da, eta tratamendu berriak depresioaren etiopatogeniaren ituetan oinarritzen hasi dira.

Patologiaren tratamendu farmakologikoaren oinarrian antidepresibo klasikoak daude. Duela hamarkada ugari aurkitu ziren, eta geroztik erabili dira: monoaminooxidasaren inhibitzaileak, antidepresibo triziklikoak eta monoaminen birxurgapenaren inhibitzaileak. Trazodona eta mirtazapina antidepresiboak, profil farmakodinamiko konplexuagokoak, urte batzuk geroago garatu ziren. Farmako talde horien eragin desiragaitz ohikoak ekiditeko eta tratamenduaren eraginkortasuna hobetzeko xedez ekintza-mekanismo alternatiboak esploratu dira, eta ikerketa horietatik sortu dira, esate baterako, agomelatina, tianeptina eta bortioxetina. Horien eraginkortasuna eta erabilera oso mugatuak dira, dena den. Ketamina, aldiz, denbora laburrean depresioaren tratamenduaren iraultza abian jarri duen substantzia izan da, sintomen hobekuntza nabarmena eta azkarra erakutsi duelako entsegu anitzetan, segurtasun eta tolerantzia egokiarekin batera. Azkenik, nabarmentzekoak dira substantzia haluzinogenoak, depresioaren eta beste gaixotasun psikiatrikoen tratamendurako erakutsi duten potentzial izugarriari esker. Depresioari dagokionez, psilozibina da psikodelikoen artean azpimarragarriena: paziente deprimituen hobekuntza azkarra eta iraunkorra eragiten badu ere, haren mekanismo antidepresiboak ezezagunak dira, eta horiek argitzeko entseguak ikerketaren gailurrean daude egun.

Gako-hitzak: Depresio nagusia, antidepresiboak, estresa, neuroinflamazioa, monoaminak, psilozibina.

\section{Abstract}

Depression is among the most common psychiatric diseases in today's society, and its incidence is steadily increasing. Many theories have attempted to explain depression's origin and

etiology, the most relevant being the monoaminergic, the neurotrophic and the neuroinflammatory hypothesis of depression, but various aspects of its neurobiology are still unknown. This review 
discusses their origin, evidence and features, along with a few other theories'. In the past, antidepressant drug discovery happened by chance, and the study of effective substances at improving symptoms contributed greatly to the knowledge of the neurobiology of depression.

Classical antidepressants constitute the base of the pharmacological treatment of depression: monoaminoxidase inhibitors, tricyclic antidepressants and monoamine reuptake inhibitors. Newer drugs, like trazodone and mirtazapine, possess a more complex pharmacodynamic profile. With the aim to avoid their usual adverse effects, and to improve their effectiveness, alternative mechanisms have been explored. This research has resulted in the discovery of substances such as agomelatine, tianeptine and vortioxetine, but their use and efficacy are not very widespread. Nonetheless, ketamine has recently revolutionised the research of antidepressants, since it has proven to be a fastacting, potent antidepressant, even in resistant cases, in addition to being safe and well-tolerated. Lastly, psychedelic substances have been known to improve symptoms of a variety of psychiatric diseases, including depression. Specifically psilocybin has shown great prospects as an antidepressant in a number of studies. Despite its undeniable beneficial effects on depressed patients, its antidepressant mechanisms are not entirely clear, and research in the field is currently trending.

Keywords: Major Depression, antidepressants, stress, neuroinflammation, monoamines, psilocybin.

Bidalia: 2020.10 .22

Onartua: 2020.11.26

http://doi.org/10.26876/osagaiz.2.2020.311

\section{Laburdurak}

PFC, kortex prefrontala; AMY, amigdala; HC, hipokanpoa; NSZ, nerbio-sistema zentrala; NSS: nerbiosistema sinpatikoa; NA, noradrenalina; DA, dopamina; 5-HT, serotonina; HPA, ardatz hipotalamikohipofisario-adrenala; GR, hartzaile glukokortikoideak; BDNF, garunetik eratorritako faktore neurotrofikoa; MAOI, monoaminooxidasaren inhibitzaileak; TCA, antidepresibo triziklikoak; SSRI, serotoninaren birxurgapenaren inhibitzaile selektiboak; SNRI, serotonina eta noradrenalinaren birxurgapenaren inhibitzaileak.

\section{Sarrera}

Depresioa egungo gaixotasun mentalik ohikoena da, eta 250 milioi pertsonak baino gehiagok pairatzen dutela estimatzen da, Osasunaren Mundu Erakundearen esanetan (1). Depresioaren intzidentzia etengabe hazi da azken hamarkadetan, eta 2030. urterako ezgaitasun-kausarik ohikoena izango dela iragartzen dute adituek (2). Gaixotasun horren ondoriorik tragikoena eragiten duen heriotza-tasa altua da, 800.000 pertsonak egiten baitute bere buruaz beste urtero, bigarren heriotzakausa ohikoena izanik 15 eta 29 urte bitarteko gazteetan. Gainera, depresioaren prebalentzia bikoitza da emakumeengan, gizonezkoengan baino (2). Patologiaren agerpenean faktore soziokulturalek garrantzia duten arren, osaera genetikoak eta beste faktore biologiko batzuk dira haren garapenaren azken erantzule.

Depresioaren sintomatologia, Gaixotasun Mentalen Diagnostikorako eta Estatistikarako Eskuliburuaren arabera (DMS-V), bederatzi zeinuk eta sintoma multzok osatzen dute, eta horietako 5 pairatu behar izan ditu subjektu batek, eta gutxienez 2 astez, depresioa dela diagnostikatzeko. Depresio nagusia gaixotasunaren formarik ohikoena da, gertakari depresibo errepikakorrek bereizia. Bestalde, tratamenduarekiko erresistente gisa sailka daiteke depresioa, bi tratamendu antidepresibok edo gehiagok sintomak kontrolatzeko porrot egin badute. Gaixotasunaren agerpenaren eperik ohikoena bizitzako bigarren eta laugarren hamarkaden erdialde bitartekoa da (2), eta apurka agertu ohi den arren, bat-batekoa ere izan daiteke. Paziente gehienek gaixotasuna gertakaritan sufritzen dute, eta zenbaitetan errepikakorrak izaten dira; gertakari horien iraupena eta kopurua aurresanezina da. Diagnosirako tresnen mugek eta nahasmenduaren osagai subjektiboek 
depresioaren diagnosia zailtzen dute; izan ere, tristura giza sentimendu naturala da, eta ez da erraza horren maila ebaluatzea. Zeregin horretarako galdeketa klinikoak aplikatzen dira, esaterako, Beck galdeketa eta Hamilton-en eskala.

Depresioaren sintomak honakoak dira: tristura, barne-hustasuna eta itxaropenik eza, anhedonia (plazera sentitzeko ezgaitasuna), pisua galtzea edo irabaztea eta jateko gogoaren galera, insomnioa edo hipersomnia, atzerapen psikomotorra, energia falta eta nekea, arreta mantentzeko zailtasuna, gutxiespen- eta erruduntasun-sentimenduak, heriotzaren edo suizidioaren inguruko ideiak (2). Gaixo deprimituek antsietate klinikoa ere maiz izaten dute (pazienteen bi heren ingurutan agertzen da, normalean depresioa bera baino 1-2 urte lehenago). Gainera, sintoma afektiboez aparte, ikusmen espazialeko arretan, oroimenean, exekuzio-funtzioetan eta beste funtzio kognitibo batzuetan desorekak dituzte pazienteek. Honek guztiak ondorio latzak dakartza gaixoen bizitzan eta maiz ezgaitasuna eta kasurik larrienetan suizidioa eragin dezakete.

Gaixotasun psikiatriko horren etiologia oraindik ezezaguna da, eta ikerketen arabera, faktore genetiko eta psikosozialekin elkarreraginez, neurotransmisioaren, hormona-mailen, immunitatesistemaren eta neurogenesiaren nahasmenduek depresioa eragiten dute. Hala ere, gaixotasunaren jatorria azaltzeko gaitasunik ezak egungo tratamenduen eraginkortasuna mugatu eta farmako berrien garapen-eskasian eragin zuzena izan du. Depresioaren tratamendu farmakologikoaren oinarria monoaminen neurotransmisio-sistemen eraginkortasuna areagotzean datza. Antidepresibo klasikoen ekintza-mekanismoa sistema serotoninergikoaren, noradrenergikoaren eta dopaminergikoaren funtzioa indartzean datza. Antidepresibo berri batzuek, aldiz, beste neurotransmisio-sistema batzuen modulazioa eragiten dute, esaterako, sistema GABAergikoa edo glutamatergikoa.

\section{Depresioaren neurobiologia}

Teoria monoaminergikoa depresioaren etiopatogeniaren lehen proposamena izan zen, 1950eko hamarkadan zehar gertatutako ezusteko aurkikuntza ugariren ondorioz. Alde batetik, iproniazida farmako antituberkulosoaren eragin antidepresiboaz ohartu ziren; bestetik, erreserpina antihipertentsiboaren efektu pro-depresiboak ikusi zituzten; azkenik, antipsikotiko gisa garatu zen imipramina farmakoa antidepresiboa zela antzeman zuten adituek. Teoria honen esanetan, garuneko monoaminen jaitsierak depresioa eragiten du. Teoria monoaminergikoak, beraz, maila zentraleko aktibitate monoaminergikoaren gutxipena adierazten du gaixotasunaren jatorritzat, sistema noradrenergikoaren, dopaminergikoaren nahiz serotoninergikoaren mekanismo sinaptikoen nahasmenduak direla eta. Hala, sinapsi-mailan gertatzen diren alterazioek garuneko hainbat eremutako funtzioa kaltetuko lukete; garrantzitsuenak dira garun-azala (portaera eta funtzio kognitiboen erantzulea), hipokanpoa ( $\mathrm{HC}$, oroimen-funtziodun eremua) eta amigdala (AMY, beldurraren eta antsietatearen erregulazio-zentroa).

Teoria hori babesten duten frogak askotarikoak dira. Esaterako, monoaminen aitzindari diren aminoazidoak dietaren bidez murrizteak depresioan berrerortzea dakar ondotik (3), baita NAren sintesia katalizatzen duen tirosina hidroxilasa entzimaren inhibizioak ere. Paziente deprimituetan azido 5-hidroxiindolazetiko eta 5-HT mailak murriztuta daude likido zefalorrakideoan, eta hori transmisio serotoninergiko murriztuaren adierazle argia da. Tratamendu antidepresibo kronikoak nahasmendu horiek normalizatzeko gaitasuna du gainera. Postmortem ikerketei dagokienez, sistema serotoninergikoaren aldaketak aurkitu izan dira gaixo deprimituen garunetako hainbat eremutan: kortex prefrontalean (PFC), AMYan eta HCan, nagusiki. Garuneko eremu horiek izaera animikoarekin erlazionatzen dira, sistema linbikoaren partaide izanik, eta ardatz hipotalamiko-hipofisarioadrenalaren (HPA) funtzioa kontrolatzen dute.

HPA estres-erantzuna erregulatzeaz arduratzen da, eta depresioaren eta hainbat gaixotasun psikiatrikoren fisiopatologiarekin erlazio estua du. Sistema honen rol fisiologikoa erantzun 
neuroendokrinoen sorrera integratua da, kanpo- eta barne-estres estimuluei aurre egiteko eta biziraupena bermatzeko. Seinalizazio-bide horren bidez, guruin adrenaletik askatutako glukokortikoideek (kortisolak) zelula barruko hartzaile espezifikoekin elkarrekintzak izaten dituzte hainbat itu-ehunetan. Alde batetik, HPAn bertan agertzen diren hartzaile glukokortikoideen (GR) kitzikatzeak ardatzaren feedback negatibo erako erregulazio-sistema gisa jokatzen du. Horrela, glukokortikoideen jariapena tarte fisiologikoan mantentzen da, eta estresarekiko gehiegizko erantzuna ekiditen da. Beste alde batetik, ehun ezberdinetako hartzaileekin elkarreragin ondoren, estres-egoerari aurre egiteko mekanismoak jartzen dira martxan, esaterako, nerbio-sistema sinpatikoaren (NSS) aktibazioa, parasinpatikoaren (NSPS) inhibizioa, bihotz-maiztasunaren eta arnasketa-maiztasunaren areagotzea, digestioaren eta hormona-jarioaren inhibizioa, karbohidratoen, lipidoen eta proteinen metabolismoaren kontrola, immunitate-sistemaren inhibizioa eta abar.

HPA ardatzaren nahasmenduak behin eta berriro aurkitu dira gaixo psikiatrikoetan, depresio nagusian bereziki. Pazienteen ehuneko handi batek du kortisolaren kontzentrazio handitua listuan, plasman eta gernuan, baita hipofisiaren aktibitate eta tamaina handituak ere (4). Ez dirudi HPA ardatzaren hiperaktibazioa depresioaren ondorioetako bat denik, patologia garatzeko arriskufaktoreetako bat baizik (5). Gaixotasun psikiatrikoetan HPA ardatzaren gehiegizko jarduera mantentzeko mekanismoa glukokortikoideekiko erresistentzia da, hau da, itu-ehunen erantzun ezeraginkorra, hormona horien aurrean. In vitro nahiz in vivo ikerketek argitu dute GR maila murriztua dagoela paziente deprimituetan, baita funtzio kaltetua ere. Era berean, postmortem ikerketen arabera, deprimituen garunetan GRaren espresioa murritzagoa da (6), eta odoleko kortisol-maila handiagoa konpentsazio-mekanismo bat izango litzateke, hartzaileekiko erantzun faltaren aurrean. Ildo beretik, tratamendu antidepresiboak HPA ardatzaren feedback negatiboa berrezartzeko gaitasuna duela ikusi da, eta hainbat entseguk ikusi dute tratamendu kronikoak GRen espresioa sustatzen duela karraskari-ereduetan. Era berean, in vitro mailan ere GRen aktibazioa eragitea lortu da antidepresiboekin, glukokortikoideekiko erresistentziari aurre eginez (7). Gehiegizko kortisolmailak garunean eragin zuzena duela frogatu da, hainbat eremutan neurogenesian eta neuroplastikotasunean nahasmenduak eraginez.

Neuroplastikotasunaren eta neurogenesiaren alterazioak ere garrantzizko prozesuak dira depresioaren patogenesian, eta hipotesi neurotrofikoan biltzen dira. Garuneko zelulek askatzen dituzten faktore neurotrofikoek neuronen eta glia zelulen garapena, biziraupena eta plastikotasuna erregulatzen dute. Teoria horren arabera, faktore horien murrizketa gertatzen da depresioan, eta anormaltasun morfofuntzionalak eragiten ditu. Faktore neurotrofikoen artean garrantzitsuenetariko bat garunetik eratorritako faktore neurotrofikoa da (brain-derived neurotrophic factor, BDNF), plastikotasun neuralaren eta neurogenesiaren erregulaziorako ezinbestekoa dena, dendriten adarkatzearen kontrolaren bidez. Paziente deprimituek BDNF espresio murriztua azaltzen dute garuneko hainbat eremutan, PFCan nahiz HCan, baita gene-espresio eraldatua ere, mRNAren murrizketa esanguratsuak adierazten duen moduan (8). Aitzitik, farmako antidepresiboak hartzen dituzten pazienteek BDNF maila handiagoak dauzkate tratatu gabekoen aldean. Bestalde, estresak eta kortisolak BDNFaren mailak alda ditzakete, eta espresioaren murrizketak eragin HCan eta PFCan.

Paziente deprimituen garunetan ikusi izan diren fenomenoen artean hauek aipa daitezke: HCaren bolumenaren galera, PFCko gune batzuen bolumen-murrizketa eta AMYaren bolumenaren aldaketak. Aldaketa morfologiko horien azalpen posible bat neurogenesiaren gutxipena da (9), faktore neurotrofikoen murrizketaren ondorioz. Esanguratsua da estres kronikoak eta glukokortikoideen epe luzeko administrazioak HCko CA3 neurona piramidaletan eragiten duten atrofia (10). Atrofia eragiteaz gain, estres-estimuluek hipokanpoko neurogenesia inhibitzeko gaitasuna dute, zelula sortu berrien kopurua murrizten baitute. Glukokortikoideak substantzia antiinflamatorioak izanik, haien funtzioaren nahasmenduek hantura-prozesuei eragin ahal diete. Izan ere, depresioa pairatzen duten pazienteetan inflamazio-egoera arina deskribatu izan da hainbat ikerlanetan. 
Paziente horietan inflamazio-egoera hori eta immunitatearen aktibazioa kontuan hartuz, eta aipatutako fenomeno guztiekin erlazionatuz, teoria neuroinflamatorioa garatu da azken hamarkadetan. Haren esanetan, periferiako zitokina proinflamatorioek hantura zentrala eragiten dute, eta epe luzean hainbat itutan eraginez, garunaren atrofia eta neurogenesiaren kalteak sortuko lituzkete (1. irudia). Nerbio-sistema zentraleko (NSZ) immunitate-sistemako zelulen artean, mikrogliak garratzi berezia du, hantura sortzen denean aktibatzen baita, zitokinen askapenaren bidez beste zelula batzuk erakartzeko eta prozesu inflamatorio-infekziosoek ehunetan eragindako kalteak konpontzeko. Periferiatik iristen diren hanturaren seinalizazioek mikrogliaren aktibazioa eragin dezakete. Paziente deprimituen garunen hainbat eremutan (HC, PFC, hipotalamoa) mikrogliaren aktibazioa deskribatu da.

Maila zentralean behatzen den inflamazio-erantzunari paraleloki, periferian ere immunitatesistemaren hiperaktibazioa gertatzen da, IL-1 $\beta$, IL- 6 , TNF- $\alpha$ eta IFN- $\gamma$ zitokina proinflamatorioen ekoizpena areagotuta agertzen baita paziente deprimituetan (11). Zitokinen kontzentrazio handiak aurkitzen dira odolean, eta haien hartzaileen espresioa ere areagotuta dago. Zitokinen kontzentrazio handi hori agerikoa da deprimituen likido zefalorrakideoan ere, eta beraz, inflamazio periferikoa maila zentralean islatzen da. Zitokina proinflamatorioak NSZera iritsi eta prozesu ugarirengan eragin dezakete (neurotransmisoreen metabolismoa, funtzio neuroendokrinoa, neuroplastikotasuna...); aldiz, ez dago argi depresioan erantzun inflamatorio zentralaren jatorria periferian dagoen, edo NSZean bertan sortzen den (12). Dena den, estres kronikoaren eta depresioaren arteko erlazio zuzena nabarmena da.

Hainbat estres mota (psikosoziala, haurtzaroko tratu txarrak eragindako estres goiztiarra) erantzun inflamatorioaren aktibazioaren eragile dira, bai periferian baita maila zentralean ere. Estresak immunitatean eragindako aktibazioaren mekanismoak NSSaren aktibazioa (katekolaminen ekoizpena) eta HPA ardatzaren aktibazioa (glukokortikoideen gehiegizko ekoizpena, haiekiko erresistentzia konpentsatzen saiatzeko) dira. Estresak induzitutako zitokinen ekoizpena NSZean mikrogliaren aktibazioaren menpe dagoela ikusi da: zelula horiek inflamazio-seinale periferikoak jasotzen dituzte, aktibatu egiten dira eta hantura-jauzia martxan jartzen dute, zitokina proinflamatorio nahiz hanturaren beste bitartekari batzuk askatuz (12). Hantura-erantzun horrek astrozitoen (glutamatoaren homeostasiaren eta neuronen ongizatea mantentzeko euskarri-zelulak) eta neuronen kaltea eta funtzioaren oztopoa eragiten dute.

Azkenik, berriki garatutako depresioaren etiopatologiaren teoriak zirkuitu kitzikatzaile eta inhibitzaileen nahasmenduak deskribatzen ditu, zehazki, glutamatoaren homeostasi eta neurotransmisioaren alterazioek eraginda (13). Glutamatoaren hipotesiak neurotransmisore horren metaketa mantendua hartzen du depresioaren kausatzat, haren askapenean, metabolismoan eta birxurgapenean gertaturiko nahasmenduen ondorioz. Funtzio kognitibo eta emozionalekin eta portaeraren erregulazioarekin lotutako garun-eremuetan (AMY, HC, PFC) sinapsiaren endekapena eta aldaketa estruktural eta morfologikoak eragingo lituzke fenomeno honek. Ebidentzia klinikoei dagokienez, glutamatoaren metabolitoak murriztuta daudela ikusi da paziente deprimituen garunazal frontal eta zingulatuan gertakari depresiboetan zehar (14), erremisioan mailak normaltzen diren arren. Gainera, gaixoen anhedonia eta atzerapen psikomotorra oinaldeko nukleoetako glutamatoedukiarekin zuzenki erlazionatu da neuroirudi bidezko ikerketaren bidez (15).

Teoria neuroinflamatorioarekin lotuz, zitokinek mikrogliak espresatzen duen indolamina 2,3dioxigenasa entzimaren indukzioa eragiten dute. Horrek triptofanoaren (Trp) degradazioa katalizatzen du, eta azido kinolinikoa metabolito neurotoxikoa ekoizten du, hain zuzen hartzaile glutamatergikoen agonista. NDMA hartzaile glutamatergikoekin elkarrekintzak agertzean, eszitotoxikotasun deituriko prozesuaren bidezko heriotza neuronala gertatzen da. Beraz, hainbat mekanismo egongo lirateke tartean zelulen heriotzan: glutamatoaren erregulazioaren nahasmenduak, azido kinolinikoaren ekoizpena eta haren bidezko NMDA hartzaileen aktibazioa, 
neurotransmisio glutamatergikoaren gainaktibazioa, astrozitoen babesaren inhibizioa, kalte neuronala, eta, azkenik, heriotza. Gainera, eszitotoxikotasunak sortutako erradikal askeek eta ondoriozko oxidazio-estresak plastikotasun neuronalaren etetea eragingo lukete (12).

1. irudia. Zitokinen ituak garunean: neurotransmisoreak eta zirkuitu neuronalak. Miller AH eta Raison CL. The role of inflammation in depression: from evolutionary imperative to modern trearment target. Nat Rev Immunol. 2016 Urt;16(1):22-34 (moldatua). IFNs (interferoiak), IL-1 $\beta$ (interleukina 1ß), IL-6 (interleukina 6), TNF (tumoreen nekrosi-faktorea), IDO (indolamino 2,3dioxigenasa), 5-HT (serotonina), DA (dopamina), NE (noradrenalina), SERT (5-HT garraiatzailea), DAT (DA garraiatzailea), NET (NA garraiatzailea), NOS (oxido nitriko sintasa), TPH (triptofano hidroxilasa), TH (tirosina hidroxilasa), MAPK (mitogenoek aktibatutako proteina kinasa), BH4 (tetrahidrobiopterina), BH2 (dihidrobiopterina), ROS (oxigenoaren espezie erreaktiboak), RNS (nitrogenoaren espezie erreaktiboak), Glu (glutamatoa), QUIN (azido kinolinikoa), EAAT2 (aminoazido kitzikatzaileen garraiatzailea 2), NMDAR (N-metil-D-aspartato hartzailea), BDNF (garunetik eratorritako faktore neurotrofikoa), NF-KB (kappa B faktore nuklearra), vmPFC (kortex prefrontal bentral-mediala), sgACC (kortex zingulatu subgenuala), dACC (zinguluko kortexaren bizkarraldeko eskualdea).

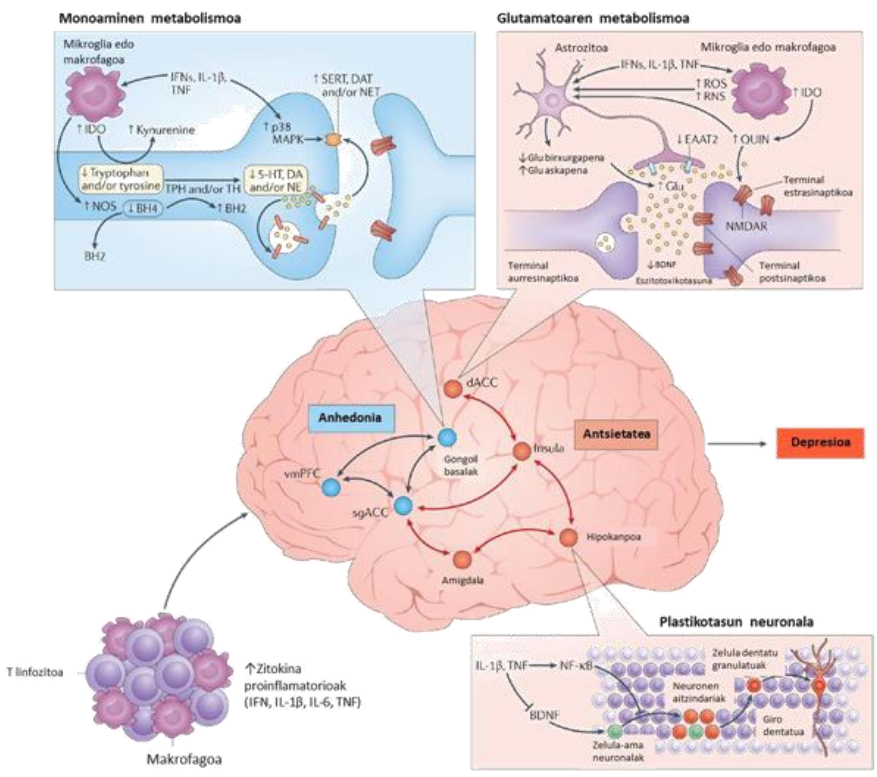

\section{Depresioaren tratamendua}

\subsection{Antidepresibo klasikoak}

50eko hamarkadan depresioaren hipotesi monoaminergikoaren garapenetik abiatuz, monoaminen neurotransmisioa areagotzen duten farmakoen diseinuari eta ekoizpenari ekin zitzaien. Modu batean edo bestean, antidepresibo klasikoek monoaminen eskuragarritasuna areagotzen dute, eta ondorioz, haien bitartezko neurotransmisioa. Aldiz, efektu biokimiko hori berehalakoa den arren, pazienteek ez dute sintomen arintzerik antzematen tratamendua hasi eta hainbat aste pasatzen diren arte. Efektu terapeutikoaren agerpenaren atzerapena eta eraginkortasun-tasa baxua farmako hauen desabantaila nagusiak dira. Ekintza-mekanismo desberdinetako molekula taldeek osatzen dute depresioaren aurkako medikazioaren biltegi terapeutiko klasikoa.

\subsubsection{Monoaminooxidasaren inhibitzaileak (MAOI)}

Monoaminooxidasek monoamina batzuen katabolismoko deaminazio oxidatiboa katalizatzen dute, besteak beste, DA, NA, 5-HT eta histamina. Bi isoentzima ditu, MAO-A eta MAO-B, substratuekiko afinitate eta ehunetako banaketa ezberdinekoak. Entzima horien inhibizioak garuneko DA, NA eta 5HT mailen areagotzea dakar. Eragin antidepresiboko entzima horien lehen inhibitzailea iproniazida 
izan zen, tuberkulosiaren aurkako botika gisa garatu zena; haren efektu psikiatrikoak ikusita, eratorriak garatu ziren, fenelzina, esaterako. Tranilzipromina, fenelzina bera eta beste MAOl ezselektibo itzulezinak depresioaren tratamendurako erabiltzen dira egun, baita itzulgarriak ere, moklobemida esaterako. Monoaminooxidasaren inhibitzaileak nahasmendu psikiatriko anitz tratatzeko erabiltzen dira, Parkinsonen gaitza, Alzheimerren gaitza eta depresioa nagusiki, eta horren baitan, depresio atipikoa tratatzeko bereziki erabilgarriak dira (16).

Toxikotasun hepatikoa, hipertentsio-krisialdiak, hemorragia larriak eta bat-bateko heriotza MAOI ugari merkatutik erretiratzearen kausa izan dira urteetan zehar (17). MAOlen eragin desiragaitzen artean aipagarria da "gazta-erreakzioa" izenez ezagutzen dena, gazta eta beste elikagai batzuetan aurkitzen den tiramina aminoazidoaren degradazioa ekiditen baitute. Ondorioz, sistema sinpatikoak bihotzean eta odol-hodietan duen eragina sendotzen du tiraminak, NAren askapena sustatuz, eta hipertentsio-krisia sufritzeko arriskua handitzen du. Erreakzio hori ekiditen duten antidepresiboak garatu dira, zehazki MAO-B isoentzimaren inhibitzaile itzulezinak, izan ere, hesteetan MAO-Ak degradatzen du tiramina dietetikoa. Bestalde, MAO-A isoformaren inhibitzaile itzulgarriek ere gaztaerreakzioa saihesten dute, maila periferikoan sortzen duten blokeoa gutxienekoa baita. Hala ere, segurtasun-profila eta eraginkortasun ertaina direla eta, ez dira asko erabiltzen gaur egun; berrikuspen sistematiko baten arabera, fenelzinaren eraginkortasun-tasa plazeboarekiko $\% 54$ ingurukoa da (18).

\subsubsection{Antidepresibo triziklikoak (TCA)}

Antidepresibo triziklikoen aurkikuntza antipsikotikoen bilaketari esker gertatu zen ustekabean, klorpromazinaren eraginkortasuna ikusita, zientzialariak antipsikotiko hobeak garatzeko ahaleginetan zeudenean. Hala, imipramina, TCA prototipikoa aurkitu zuten, antipsikotiko gisa porrot egin zuena, baina eragin antidepresiboa erakutsi zuena. Antidepresibo horiek monoaminen birxurgapena inhibitzen dute eta hartzaile muskarinikoen, histaminergikoen, serotoninergikoen eta adrenergikoen blokeoa eragin. Propietate farmakologiko egokienak dituen TCA nortriptilina da, tarte terapeutiko zabala duelako. Gainera, beste TCA batzuk ez bezala, MAOlekin eta beste antidepresibo batzuekin batera hartzeko segurua da (19). Hau abantaila garrantzitsua da depresio errepikakorra duten pazienteetan, terapia konbinatuak behar dituztenean.

Aipatutako hartzaileekin dituzten elkarrekintzak TCAen eragin desiragaitz gehienen erantzule dira (eragin antimuskarinikoak eta sedazioa). Aipagarria da $H_{1}$ hartzaile histaminergikoen eta $\alpha_{1}$ adrenohartzaileen blokeoaren ondorioz eragiten duten sedazioa: antsiolisia terapeutikoa izan daiteke pazienteek agitazioa pairatzen dutenean, baina erabilera kronikorako eragin desiragaitz larria bihur daiteke, onartezina ere kasu askotan. Egun ez dira lehen aukerakoak, segurtasun-profila dela eta, beraz, beste antidepresiboekin konbinatuta edo beste farmakoek porrot eginez gero erabiltzen dira.

\subsubsection{Monoaminen birxurgapenaren inhibitzaileak}

Orain arte aipatutako antidepresiboak ez bezala, serotoninaren birxurgapenaren inhibitzaile selektiboak (SSRI) ekintza-mekanismo zehatza helburu izanik espresuki diseinatutako lehen farmako psikotropikoak izan ziren, hartzaileen in vitro binding teknologia erabiliz garatuak. Garapen horren jomuga eragin terapeutikoak lortzeko eta eragin desiragaitzak ekiditeko ekintza-mekanismo konkretua aurkitzea zen, baita TCA eta MAOlak baino seguruagoak ziren farmako antidepresiboak diseinatzea ere. Fluoxetina izan zen merkaturatu zen lehena, 1987an, eta geroztik, farmako talde hau depresioaren tratamendurako erabiliena bihurtu da. SSRI guztiek partekatzen duten ekintza farmakologikoa 5-HTaren garraiatzaileen blokeoa da, era haren eskuragarritasuna areagotzea NSZean; hala ere, talde horretako molekula batzuek hartzaile serotonergikoekiko afinitatea dute, eta agonista edo antagonista gisa jokatzen dute hartzaile azpitalde batzuetan. SSRI erabilienetakoak zitalopram, eszitalopram, fluoxetina, paroxetina eta sertralina dira. Depresioa eta beste asaldura 
psikiatriko batzuk tratatzeko indikazioak dituzte (antsietate-nahasmendua, nahasmendu obsesibokonpultsiboa, trauma ondoko estres-nahasmendua eta abar) (20).

Eraginkortasun klinikoa tratamendua hasi eta 2 astera agertzen da, eta eraginkorrak dira pazienteen $\% 60$ inguruan. Orokorrean, SSRlak ondo toleratzen dituzte pazienteek, eta eragin desiragaitzak gehienetan larriak ez diren arren, epe luzean tratamendua bertan behera uztera bultza dezake. Horietako batzuk dira, adibidez, hesteetako asaldurak (okadak eta beherakoa), buruko mina, zorabioak, loaren alterazioak (hipersomnia edo insomnioa), pisu irabaztea eta disfuntzio sexuala. Azken hori oso ohikoa da, pazienteen ehuneko altu batek sufritzen baitute, eta ez dute tolerantziarik garatzen.

Noradrenalinaren birxurgapenaren inhibitzaile selektiboek (NRI) NAren garraiatzailea blokeatzen dute NSZean, eta, hartzaileekiko afinitate txikiari esker, eragin desiragaitz urriak eragiten dituzte. Erreboxetinak eraginkortasun kliniko nabarmena erakutsi du depresioaren tratamenduan, tratamenduarekiko erresistentea den depresioa barne (21). Esan bezala, eragin desiragaitzak eskasak dira, eta ez du efektu kardiobaskular kaltegarririk eragiten, ezta kognitibo edo motorrik ere. Erabilgarriak dira SSRIen kontraindikazioan edo pazienteek min neuropatikoa badute.

Serotonina eta noradrenalinaren birxurgapenaren inhibitzaileek (SNRI), edo inhibitzaile mistoek, duloxetina eta benlafaxina besteak beste, 5-HT eta NAren xurgapena blokeatzen dute tarte sinaptikotik. Benlafaxina da ezagunena eta erabiliena, baina kostu altua dela eta, erresistentzia kasuetan bakarrik erabiltzen da. SNRlen eraginkortasuna SSRIena baino hobea dela uste izan den arren, meta-analisi batek depresio nagusian duten eraginkortasun klinikoa parekoa dela aurkitu zuen (22).

\subsubsection{Beste antidepresibo klasikoak}

Triziklikoen eragin desiragaitzak saihestuz, haien eraginkortasuna berdintzeko farmakoen bilaketan hainbat antidepresibo garatu ziren XX. mendearen bigarren zatian.

Trazodona 1960ko hamarkadan garatu zen bigarren belaunaldiko antidepresiboa da. Haren ekintzamekanismoa mistoa da: alde batetik, 5-HTaren birxurgapena blokeatzen du; bestetik, hartzaile serotoninergikoekin elkarrekintzak egiten ditu. Antagonista gisa jarduten du, 5- $\mathrm{HT}_{2 \mathrm{~A}}$ hartzaileengan, baita $5-\mathrm{HT}_{2 \mathrm{~B}}$ eta $5-\mathrm{HT}_{2 \mathrm{C}}$-engan, eta agonista partzial gisa, $5-\mathrm{HT} \mathrm{T}_{1 \mathrm{~A}}$ hartzaileengan. Beste hartzaile batzuekin ere elkarrekintzak burutzen ditu, besteak beste, $H_{1}$ eta $\alpha_{1}$ hartzaileekin, haiek blokeatzearen bidez efektu sedatzaile-hipnotikoa baitu. Trazodonaren eraginkortasuna depresio nagusiaren sintomen kontrolean TCA, SSRI eta SNRlenaren antzekoa da; aldiz, esan bezala eragin hipnotikoa duenez, sintoma jakin batzuk (insomnioa) tratatzeko erabiltzen da, maiz beste antidepresibo batzuekin konbinatuta. Orokorrean ondo toleratzen den arren, farmako horren eragin desiragaitz ohikoenak logura, migraina, zorabioa eta aho-lehortasuna dira (23).

Mirtazapinak sistema serotoninergikoarengan nahiz noradrenergikoarengan eragiten du. Antidepresibo tetrazikliko honen profil farmakologikoa nahiko zabala da: sinapsi aurreko $\alpha_{2}$ adrenohartzaile inhibitzaileak blokeatzen ditu (NAren askapena handitzen du tarte sinaptikoan), baita neurona serotoninergikoetako $\alpha_{2}$ heterohartzaileak ere (5-HTaren askapena bultzatzen $\mathrm{du}$ ). Beste alde batetik, $5-\mathrm{HT}_{2}$ eta $5-\mathrm{HT}_{3}$ hartzaileen antagonista da, eta $5-\mathrm{HT}_{1 \mathrm{~A}}$ eta $\mathrm{H}_{1}$-en agonista. Eraginkortasun klinikoari dagokionez, mirtazapina eraginkorra da plazeboarekin alderatzen denean. Beste antidepresiboen alboan, aldiz, eraginkortasuna antzekoa da, bai SSRlekiko, bai TCAekiko. Horiekiko abantailarik erakusten ez duenez, ez da lehen aukerako farmakoa. Mirtazapinaren eragin desiragaitzik aipagarriena pisua hartzea da. Abantaila nagusien artean ditugu eragin desiragaitz sexualen falta, adineko pazienteen tolerantzia ona eta eragin kardiobaskular urriak (24). 


\subsection{Antidepresibo berriak}

Antidepresibo klasikoen eraginkortasuna orokorrean eskasa da, eta eragin desiragaitzak, aipagarriak. Hori hala izanik, azken hamarkadetan zientzialariak ekintza-mekanismo alternatiboak bilatzen eta proposatzen saiatu dira, gaixotasun horren neurobiologiarren inguruko ezagutzak hazten joan diren heinean, depresioaren aurkako tratamendua hobetzeko. Nolanahi ere, substantzia berri horien eraginkortasuna oso mugatua da, baita erabilera ere. Agomelatinaren profil farmakologikoa bereizgarria da beste antidepresiboen aldean: melatonina neuro-hormonaren hartzaileen ( $\mathrm{MT}_{1}$ eta $\mathrm{MT}_{2}$ ) agonista da. Afinitate ertaina du 5-HTaren hartzaile batzuekiko, eta 5- $\mathrm{HT}_{2 \mathrm{c}}$-aren antagonista da. Ekintza antidepresiboa neurogenesia areagotzeko gaitasunari esker lortzen duela uste da, bereziki HCan, BDNFaren produkzioa bultzatzen baitu (25). Ikerketa batzuetan agomelatinaren eraginkortasuna antidepresibo arruntenen parekoa dela ikusi da, eta tolerantzia egokia duela depresio nagusia duten pazienteetan (26). Hala ere, oraindik ez dago emaitza arrakastatsu nahikorik lehen aukerako farmako gisa erabiltzea justifikatzen duenik, inondik inora.

Tianeptinak, nitrogeno eta sufre atomodun konposatu heteroziklikoa, propietate antsiolitiko eta antidepresiboak dauzka, eta ez du sedaziorik eragiten. Depresioaren sintoma kognitibo eta somatikoak hobetzen ditu, nahasmendu digestiboak barne (27). Haren profil farmakologikoa erabat ezberdina da; $\mu$ hartzaile opioideekin interakzionatzen du, glutamatoaren funtzioa modulatzen du eta HPA ardatzaren hiperaktibazioa murrizten du, estresak eragindako HC-ko neuronen atrofia geldiaraziz. Mekanismo bereizgarri horiek eta mekanismo klasikoen absentziak azaldu lezakete tianeptinaren eraginkortasuna SSRIei erantzun ez dieten pazienteengan (28), baina berriro ere, ebidentzia horiek ez dira nahikoak tratamendua bermatzeko.

Bortioxetina antidepresibo berriaren ekintza-mekanismoa guztiz argi ez dagoen arren, in vitro entseguen arabera, hartzaile serotoninergikoen antagonista eta agonista partzial gisa jarduten du, eta 5-HTaren garraiatzailea blokeatzen du (29). In vivo datuei dagokienez, 5-HT estrazelularraren igoera eragiten du HCan, NArena PFCan eta HCan, eta azetilkolinarena PFCan. Proposatu da azken mekanismo hori dela hobekuntza kognitiboaren erantzule. Epe laburreko eta epe luzeko entseguek bortioxetinaren arrakasta klinikoa erakutsi dute depresio nagusi ertaina edo larria duten pazienteetan, bereziki hobekuntzaren ondoren berriro okerrera egitea ekiditeko orduan (30). Dena den, 2017ko berrikuspen baten esanetan, bortioxetinak depresioaren tratamenduan duen lekua ez legoke argi: beste antidepresiboekin alderatuta ez duelako abantaila handirik aurkezten, ez delako SSRlekiko konparazio-azterketarik egin, eta gainerako konparazio-ikerketen kalitatea eskasa delako (31).

Azken urteetan depresioaren tratamenduan benetako iraultza eragin duen farmako bakarra ketamina izan dela esan genezake, haren berehalako eraginari esker bai depresio nagusian, bai tratamenduarekiko erresistentea den depresioan. Jatorrian anestesiko disoziatibo gisa garatu zen $60 \mathrm{ko}$ hamarkadan, eta ondoren aisialdiko erabilera zabaldu zen. Anestesiko gisa abantaila ugari ditu: efektu hipnotiko, analgesiko eta amnesikoak ditu aldi berean, eta arnasketa-sistemaren eta sistema kardiobaskularraren egonkortasuna mantentzen du (32). Bere kabuz, nahiz propofolarekin konbinatuta, anestesiko bezala erabiltzen da egun, fitxa teknikoak adierazten duen indikazio bakarra delako.

Bestalde, hainbat hamarkada beranduago, ketaminaren dosi subanestesikoek egoera depresiboaren hobekuntza bizkorra eragiten dutela frogatu zen. Bere eragin antidepresiboa ebaluatzeko lehen entseguan bertan, ketaminak sintomatologia depresiboaren hobetze izugarria erakutsi zuen (33). Ikerlan horretan zain bidezko dosi bakarrak pazienteen Depresiorako Hamilton Eskalaren (Hamilton Depression Rating Scale, HDRS) puntuazioa nabarmen murriztu zuen. Geroztik, itsuak ziren, ausazkotutako eta plazeboarekin kontrolatutako entsegu kliniko ugarik haren antzeko emaitzak aurkeztu dituzte (34), eta substantzia horren eraginkortasuna frogatu dute. Bereziki nabarmena da 
tratamendu farmakologikoarekiko erresistentzia eta terapia elektrokonbultsiboaren eraginkortasun eza erakutsi duten pazienteengan duen efektua. Horrez gain, portaera suizidaren murrizketa esanguratsua eragiten du ketaminak.

Ketamina $R$ - eta $S$ - enantiomeroen nahaste errazemikoa da. Bigarrena esketamina izenez ezagutzen da eta aktibitate analgesiko eta anestesiko handiagoa du ketaminak baino, baita efektu psikomimetiko gutxiago ere (35). Ketamina eta esketaminaren ekintza-mekanismoa NMDA hartzaile glutamatergikoaren antagonismoa da. Aldiz, ketaminaren eragin antidepresibo azkar eta iraunkorra ezin da NMDA hartzaileen blokeoagatik soilik azaldu. Hartzaileen blokeo horrek mekanismo eta egokitze-aldaketak martxan jartzen ditu, eta ketaminaren eragin akutuak aktibatutako seinaleztapenbideek neurogenesia bultzatzen dute, BDNFaren ekoizpenaren bidez. Era horretan, ketamina eta esketaminaren efektu antidepresiboaren jatorria glutamatoaren askapenaren eta haren hartzaileen interakzioaren modulazioan aurkitzen da; fenomeno horiek martxan jartzen dituzten eraldaketa morfologiko neuronalek, azkenean, gogo-aldartearen gaixotasunen estres-erantzun ezegokia normalizatuko lukete. Hori, beraz, depresioan agertzen den atrofiaren aurkako ekintza-mekanismoa izan liteke.

Administrazio-bide egokienaren bilaketan hainbat zailtasun sortu dira, eta zain bidezkoa edo aho bidezkoa albo batera utzi dira, infekzioak eta beste eratako konplikazioak eta bioerabilgarritasun txikia baitituzte, hurrenez hurren. Erosotasuna eta erabilgarritasunaren nahiz segurtasunaren arteko orekaren bila, sudur bidezko bidea proposatu da: zain bidezkoarekiko eraginkortasun parekoa du, tolerantzia-profil hobeaz gain. Sudur bidezko esketaminaren eraginkortasuna eta segurtasuna suizidio-arriskudun pazienteengan ikertu duen entsegu bat argitaratu da berriki. Horren emaitzen arabera, bere buruaz beste egiteko burutazioen murrizketa esanguratsua eta oso azkarra eragin zuen (lehen dosia eman eta 4 ordura), sintoma depresiboen murrizketa adierazgarria dosia eman eta 11 egun igaro ziren arte, eta tolerantzia ona erakutsi zuen (36).

Ketaminak eragin antidepresibo sendo eta azkarra, segurtasun onargarria eta tolerantzia-profil egokia erakutsi du entsegu klinikoetan. Tratamenduarekiko erresistentea den depresioan ere hobekuntzak eragiten ditu, suizidio-asmoak murrizteaz gainera. Emaitza horiek guztiek erabilgarritasun handia ematen diote farmakoari, baina zenbait alderdi eztabaidan eta argitzeke daude oraindik: badirudi dosi bakarraren efektuaren iraupena astebete ingurukoa dela, eta posologia egokiena zehazteko ikerketa gehiagoren beharra dago. Bi enantiomeroen potentzia eta efektua alderatzen duten entsegu batzuek emaitza kontrajarriak lortu dituzte (37), bai segurtasunari dagokionez, baita eraginaren iraupenari dagokionez ere; administrazio-bideen bioerabilgarritasuna eta eraginkortasunaren baliokidetasuna alderatzen dituzten ikerketak egitea ere komenigarria litzateke. Horrez guztiaz gain, in vitro eta animalia-entseguak ezinbestekoak izango dira ketaminaren ekintza-mekanismo zehatza argitzeko, sistema glutamatergikoan eta neurogenesian nola eragiten duen aurkitzeko xedez.

\subsection{Etorkizuneko antidepresiboak}

Berriki garatu diren farmako antidepresiboen emaitzak aldakorrak dira, aurreko atalean azaldu den bezala: batzuek potentzial handia izanik, etorkizun hurbilean erabilera zabaltzeko aukera emango dute (ketamina); beste batzuek, eraginkortasun ertaina eta aplikazio kliniko mugatua dute (agomelatina, tianeptina). Depresioaren neurobiologiaz gehiago jakin dugun neurrian, erabat bestelako bideak proposatu dira haren tratamendurako. Arlo horretan substantzia haluzinogenoak gailentzen dira, eta psikiatrian aspalditik ezagutzen eta erabili izan diren arren, azken urteetan haienganako interesa eta ikerketarako finantziazioa berpiztu egin dira.

Psikodelikoak ere deituak, erabilera zabala izan zuten 40ko eta 60ko hamarkaden bitartean, neurologiaren eta psikiatriaren eremuetako ikerketa terapeutikoan. Zoritxarrez, 1960tik aurrerako 
aisialdiko erabilerak eta legez kanpo saltzeak hondamendia ekarri zuen psikodelikoen ikerketara (38). 1970. urtetik aurrera azido lisergikoaren dietilamida (LSD), psilozibina, 3,4metilendioximetanfetamina (MDMA) eta beste hainbat substantzia haluzinogeno Amerikako Estatu Batuetako Drogen Kontrolerako Administrazioak (Drug Enfocement Administration, DEA) Kontrolpeko Substantzien Legearen I. Sailkapenean (Schedule I, Controlled Substance Act) sartu zituen, eta haien erabilera erabat legez kanpo utzi zuen. Sailkapen horren barne jasotzen diren substantziek ez dute erabilera mediko aitorturik, gaizki erabiltzeko arrisku potentzial handia dute eta haien erabilera arriskutsua kontsideratzen da.

Legearen murriztapenek ikerketa izugarri mugatu duten arren, debekuen aurretik egin ziren entseguek nahiz azken hamarkadetan eskuratu diren datuek psikodelikoen eragin terapeutikoen ebidentzia oparoa iradokitzen dute. Gaixotasun psikiatriko ugaritan frogatu da substantzia mota horien eraginkortasuna, kasurako, depresioan, antsietatean, asaldura obsesibo-konpultsiboan, adikzioan eta trauma-ondoko estres-asalduran (potentzial terapeutikoen berrikuspena: 38 ). Depresioan zentratuz, hainbat molekula aztertu dira entsegu klinikoetan. Paziente kopurua oso mugatua den arren, eta baldintza klinikoak murriztaileak, emaitza harrigarriak lortu dira konposatu horiekin.

\subsubsection{Psilozibina}

Psilozibina jatorri naturaleko substantzia haluzinogenoa da, Psilocybe generoko onddoek ekoiztua nagusiki. Alkaloide hau triptaminaren eratorria da, eta aho bidez kontsumitzean, berehalako metabolismo hepatikoaren bidez psilozina bilakatzen da, defosforilazio-erreakzioa dela medio. Kultura batzuetan gizakiek mendeetan zehar kontsumitu dute psilozibina testuinguru erlijiosoan eta giro espiritualean, Erdialdeko eta Hego Amerikan bereziki. Efektu akutuen artean pertzepzioaren (ikusmen-haluzinazioak, sinestesia), kognizioaren eta portaeraren aldaketak aipa daitezke. Eragin psikologiko garrantzitsuak ere baditu, esaterako, erlaxazioa, barregura, emozio-atariaren aldaketak (sugestio-mailaren jaitsiera) eta abar.

Psilozibinaren kontsumoak eragiten dituen onura psikologikoak behin eta berriro frogatu dira boluntario osasuntsuekin egindako ikerlanetan (39, 40, 41). Eragindako efektu psikologikoen artean afektu positiboen areagotzea eta negatiboen murriztea, esperientzia espiritual-mistikoak, esangura pertsonal handiko bizipenak, jarrera-aldaketa positiboak, gogo-aldartearen eta bizi-kalitatearen hobekuntza dira aipagarrienak. Subjektu osasuntsuetan psilozibina-dosi bakarrak edo bi dosik eragin ditzaketen efektu onuragarriak ikusita, zenbait nahasmendu psikiatrikoengan dituzten eraginak esploratu dira. Depresioaren tratamendurako psilozibinarekin egin diren entsegu klinikoak ebaluatzen dituen meta-analisi baten arabera, psilozibinak depresioaren eta antsietatearen murrizketa esanguratsua eragin zuen entsegu guztietan (42), eta epe luzeko jarraipena egin zen kasuetan, efektuak esanguratsuak mantendu ziren tratamendua burutu eta hiru hilabetera (2. irudia).

Psilozibinaren erabileraren alderdi oso garrantzitsu bat testuingurua da. Psikodeliko gehienekin gertatzen den moduan, ingurugiroak nahiz kontsumitzailearen egoera psikologikoak esperientzia psikodelikoan eragin izugarria dute (43). Horregatik, entsegu klinikoetan psikodelikoez lagundutako psikoterapiaz hitz egiten da: psilozibinaren administrazioa aho bidez egiten da psikoterapia-sesio baten barnean, eta beti inguru klinikoan. Esan bezala, saio psikodeliko bakarra edo denboran banatutako bi aurrera eramaten dira kasu gehienetan, eta pazienteak euskarri psikologikoa jasotzen du saioaren aurretik, saioak irauten duen bitartean eta ondoren (44). Tratamendu antidepresibo klasikoaren alboan, psilozibinaren erabilerak eredu terapeutikoaren erabateko aldaketa planteatzen 
du, terapia psikologikoaren garrantzia nabarmentzen baitu, eta posologiaren sinplifikazioa, baina baita baliabide profesionalen beharra ere.

2. irudia. Depresioaren Beck Depression Inventory (BDI) eskalaren puntuazioak psilozibinarekin egindako entsegu baten 12 pazienteetan. Paziente bakoitzak BDI eskalan lortu zuen hasierako puntuazioa, psilozibina dosia jaso eta astebetera, eta 3 hilabetera lortutako puntuazioa adierazten dira. Puntuazioaren jaitsiera esanguratsua izan zen paziente guztietan, sintoma depresiboen hobekuntza azkarra adieraziz. Gainera, hobekuntza denboran mantendu zen kasu gehienetan. Carhart-Harris RL, Bolstridge M, Rucker J, Day CM, Erritzoe D, Kaelen M, Bloomfield M, Rickard JA, Forbes B, Feilding A, Taylor D, Pilling S, Curran VH, Nutt DJ. Psilocybin with psychological support for treatment-resistant depression: an open-label feasibility study. Lancet Psychiatry. 2016 Uzt;3(7):619627 (moldatua).

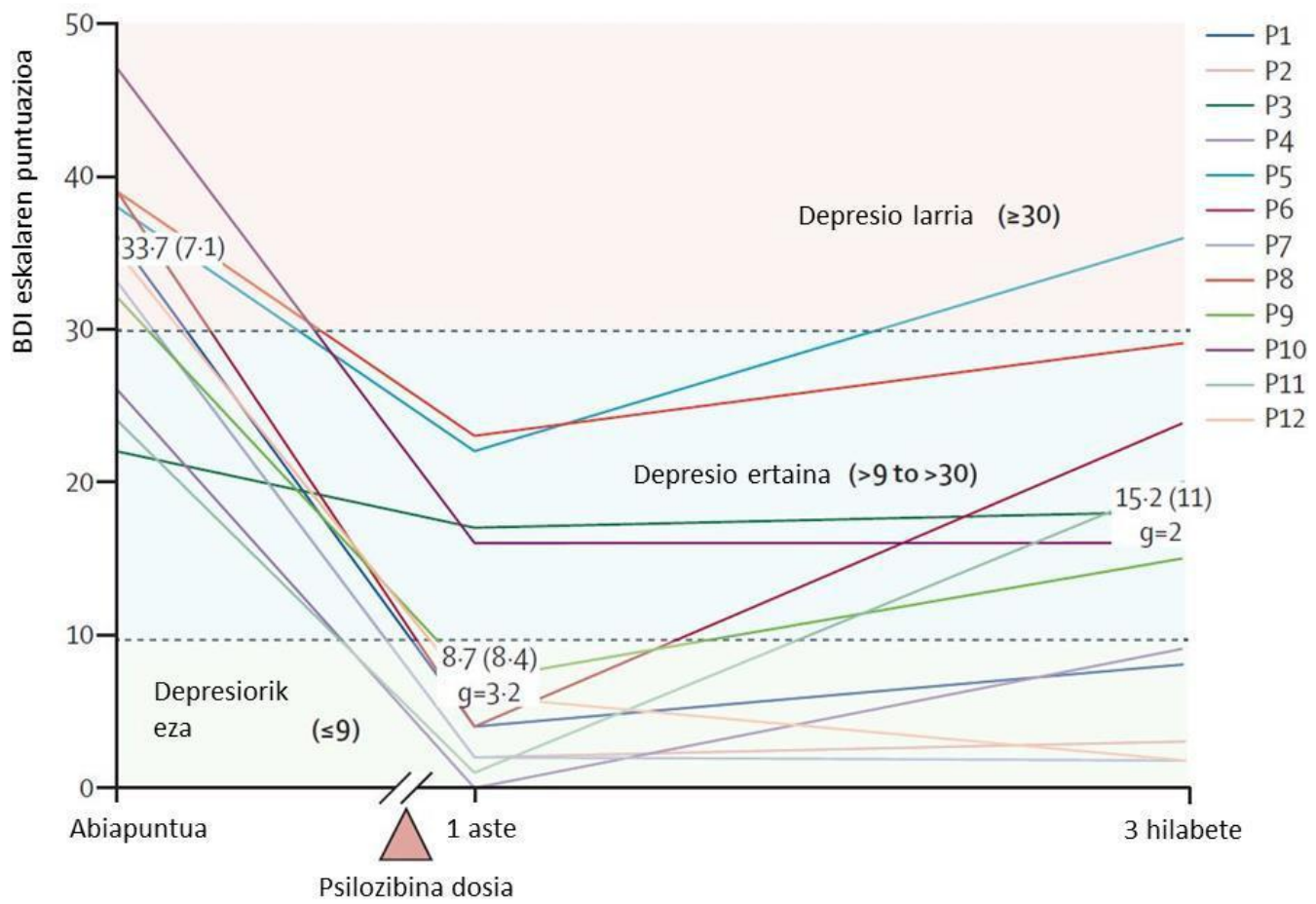

Psilozibinaren ekintza-mekanismoari dagokionez, $5-\mathrm{HT}_{2 \mathrm{~A}}$ hartzaileen afinitate handiko agonista da, eta garun-azaleko hartzaile horiek estimulatuz eragiten ditu haluzinazioak, gainerako haluzinogeno klasikoek bezala (45). Beste hartzaile serotoninergiko batzuekin ere elkarrekintzak ditu (5-HT1A, 5$H T_{2 c}$ ), baina afinitate txikiagoz. Hartzaile neuronaletan eragitean, psikodelikoen eragin akutuak azal daitezke, haien blokeo farmakologikoak (46) edo ezabapen transgenikoak (47) eragin haluzinogenoak saihesten dituzte eta. Hala ere, psilozibinaren eragin antidepresiboaren ekintza-mekanismoa ez dago guztiz argi, ezta denboran duen iraupenarena ere. Proposatu diren hipotesien arabera psikodelikoek plastikotasun neuronala eragiten dute, eta ildo horretatik, epe luzeko aldaketa morfologikoek eragin antidepresibo mantendua azalduko lukete. Aldaketa morfologikoetatik eratorritako aldaketa funtzionalen ebidentziak ere badaude: neuroirudi bidezko ikerketa ugarik aldaketak aurkitu dituzte pazienteen zirkuitu neuronaletan, esaterako, konektibitate funtzionalaren murrizketa AMY eta PFCaren artean (48). Garuneko bi eremu horien arteko komunikazioaren murrizketa sintoma depresiboen hobekuntzarekin lotu da gainera. Hortaz, benetako erronka da gaur egungo zientziarentzat psilozibinaren efektu akutuen eta kronikoen arteko erlazioa argitzea.

\subsubsection{Beste haluzinogeno batzuk}

Psilozibinak etorkizun handieneko substantzia dirudi haluzinogenoen artean, haren segurtasun-profil onari, tolerantzia egokiari eta farmakozinetika azkarrari esker, baina beste zenbait molekulak ere emaitza positiboak erakutsi dituzte depresioaren tratamendurako entseguetan. Esaterako, aiahuaska 
edabe tradizionala, Amazoniako errituetan kontsumitzen dena, depresio erresistentearen tratamendurako frogatu da. Aiahuaskaren efektu psikoaktiboa haren osagai aktiboari, dimetil triptaminari (DMT), egozten zaio, 5- $\mathrm{HT}_{2 \mathrm{~A}}$ hartzaileen agonista dena, hain zuzen (49). Aiahuaskak sintoma depresiboen murrizketa esanguratsua eragiteaz gain, eragin antsiolitikoa ere badu, denboran iraunkorra dena. Entsegu itsu bikoitz batean eraginkortasuna aurkeztu zuen aiahuaska-dosi bakarrak, plazeboarekin alderatuta (50).

Efektu horiek paziente deprimituetan frogatzeaz gain, entsegu aurreklinikoek animalia-ereduetan erreplikatzea lortu dute. Animalien portaera-probetan sintomatologia depresiboaren adierazle diren jokabideak murrizten ditu, eta parametro neurokimikoak aldatu. Besteak beste, BDNFaren areagotzea behatu da saguen HCan. Horrez gain, depresioaren eredu diren primateetan egindako entseguetan aiahuaska-dosi bakarrak sintomen hobekuntza eragiten duela ikusi da (49). Ebidentzia horiek guztiek aiahuaskaren potentzial antidepresiboa agerian uzten dute, baina goiz da depresioaren tratamenduan izan dezakeen papera erabakitzeko.

\section{Ondorioak}

Depresioa ohiko gaixotasun psikiatrikoa da, haren intzidentzia geroz eta altuagoa da eta gizartearentzat dakarren zama sanitarioa, ekonomikoa eta soziala, larria. Badakigu haren garapenean faktore anitzek eragina dutela, baina ez dugu haren jatorriaren ezagutza zehatzik.

Depresioan agertzen diren alterazio neurobiologikoak deskribatu dira ikuspuntu ezberdinetatik. Teoria monoaminergikoaren arabera, monoamina-mailen jaitsierak depresioa eragiten du, eta hala demostratzen dute gaixoen garunen postmortem ikerketek, nahiz monoaminen aitzindarien faltak eragindako berrerortzeak deskribatzen dituzten entseguek. HPA ardatzaren estres-erregulazio funtzioa hondatuta dago paziente deprimituetan, eta haren hiperaktibitatea deskribatu da, glukokortikoideekiko erresistentziaren bidez mantentzen dena. Ardatz horren funtzionamenduan inplikatutako hartzaile zelularren espresioa ere aldatuta dago. Hipotesi neurotrofikoari dagokionez, depresioan agertzen diren neuroplastikotasunaren eta neurogenesiaren nahasmenduak deskribatzen ditu. Faktore neurotrofikoen murrizketak garuneko anormaltasun morfofuntzionalak eragiten ditu, gaixoen garun-azterketek adierazten duten moduan, besteak beste, HCaren, PFCko gune batzuen eta AMYaren bolumenaren aldaketak ageri dira eta. Teoria neuroinflamatorioak pazienteen inflamazioegoera eta sistema immunearen aktibazioa hartzen ditu depresioaren eragiletzat, periferiako zitokina proinflamatorioek hantura zentrala eragiten baitute. Maila zentralean, hantura-erantzuna mikrogliaren aktibazioari esker bideratzen da, estresak eta beste faktore batzuek induzituta. Mikrogliaren aktibazioak dakarren zitokinen askapenak astrozitoen eta neuronen kaltea eragiten du. Azkenik, glutamatoaren hipotesiaren arabera, neurotransmisore kitzikatzaile horren askapena, metabolismoa eta birxurgapena kaltetuta egoteak sinapsi neuronalen endekapena ekarriko luke, portaerarekin, emozioekin eta kognizioarekin lotutako garun-eremuetan. Epe luzera sortutako aldaketa estruktural eta morfologikoak depresioaren sintoma gisa adierazten dira.

Antidepresiboek aipatutako nahasmendu gehienen normalizazioa eragiten dute, eta bide batez sintomen kontrola ahalbidetzen dute, pazienteen ehuneko batean. Aldiz, haien eraginkortasun-tasa ez da bikaina, eta gehienetan, eragin desiragaitz ertain eta larriak agertzen dira tratamenduan zehar. Antidepresiboen artean gehien erabiltzen dira klasikoak deiturikoak, haien aurkikuntza aspaldikoa izanagatik ere. TCA, MAOI eta monoaminen birxurgapenaren inhibitzaileak lehen edo bigarren aukerakoak dira depresioaren tratamenduan, baina maiz egiten dute porrot sintomen hobekuntzan. Bigarren belaunaldiko antidepresiboek, mirtazapina eta trazodona, tratamenduaren hobekuntza arina ekarri zuten, baita segurtasun-profilarena ere; hala ere, haien eragin desiragaitzak askotarikoak dira, eta larriak izan daitezke.

Farmako berritzaileagoen artean ekintza-mekanismo ezberdinak begiesten dituztenak aurki ditzakegu: agomelatina, tianeptina eta bortioxetina. Eraginkortasun mugatua dute, kasu askotan ez 
dira plazeboa baino hobeak, eta haien erabilera ez dago oso hedatuta. Azken hamarkadan beste batzuen gainetik nabarmendu den farmakoa ketamina izan da, haren eragin antidepresibo azkarragatik, tolerantzia onari eta segurtasun egokiari esker, eta entsegu kliniko asko garatzen ari dira egun, dosien eta posologiaren diseinu egokirako bereziki.

Depresioaren tratamendu berrien ikerketaren ildoan aurrea hartu dute substantzia haluzinogenoek. Oso fase goiztiarretan daude, haien erabilera mugatzen duen legeria zorrotza dela medio, baina orain arte burututako entsegu klinikoek emaitza oparoak eman dituzte. Psikodelikoek potentzial izugarria dute gaixotasun psikiatrikoen tratamendurako, eta bereziki nabarmena da psilozibinaren eragina depresioa duten pazienteetan. Psilozibinaren nahiz beste haluzinogenoen mekanismoak argitzea ezinbestekoa da haien erabilera eta segurtasun optimoa bermatzeko. Horretarako, in vitro nahiz in vivo entseguak, animalia ereduak eta beste tresna batzuk erabiltzen dituzten ikerketa-proiektuak garatu beharra dago. Gaixotasun psikiatrikoen tratamenduaren norabide berria markatu lezakete substantzia hauek eta pazienteen bizi-kalitatearen hobekuntzan lagundu.

\section{Erreferentzia bibliografikoak}

1. World Health Organization [Internet]. Geneva: World Health Organization, c2020. Depression. Fact sheet: 2020 Urt 30 [Kontsulta: 2020-04-12]; [3 or.]. Eskuragarri: https://www.who.int/newsroom/fact-sheets/detail/depression

2. Malhi GS, Mann JJ. Depression. The Lancet. 2018 Aza;392(10161):2299-2312.

3. Delgado PL, Charney DS, Price LH, Aghajanian GK, Landis H, Heninger GR. Serotonin function and the mechanism of antidepressant action. Reversal of antidepressant-induced remission by rapid depletion of plasma tryptophan. Arch Gen Psychiatry. 1990 Mai;47(5):411-418.

4. Nemeroff $C B$, Vale $W W$. The neurobiology of depression: inroads to treatment and new drug discovery. J Clin Psychiatry. 2005;66 Suppl 7:5-13.

5. Pariante CM, Lightman SL. The HPA axis in major depression: classical theories and new developments. Trends Neurosci. 2008 Ira;31(9):464-468.

6. López JF, Chalmers DT, Little KY, Watson SJ. A.E.Bennet Research Award. Regulation of serotonin1A, glucocorticoid and mineralocorticoid receptor in rat and human hipoccampus: implications for the neurobiology of depression. Biol Psychiatry. 1998 Api 15;43(8):547-573.

7. Pariante CM, Pearce BD, Pisell TL, Owens MJ, Miller AH. Steroid-independent translocation of the glucocorticoid receptor by the antidepressant desipramine. Mol Pharmacol. 1997 Urr;52(4):571581.

8. Dwivedi Y, Rizavi HS, Conley RR, Roberts RC, Tamminga CA, Pandey GN. Altered gene expression of brain-derived neurotrophic factor and receptor tyrosine kinase $B$ in postmortem brain of suicide subjects. Arch Gen Psychiatry. 2003 Abu;60(8):804-815.

9. Sterner EY, Kalynchuk LE. Behavioral and neurobiological consequences of prolonged glucocorticoid exposure in rats: relevance to depression. Prog Neuropsychopharmacol Biol Psychiatry. 2010 Eka 30;34(5):777-790.

10. McEwen BS. Stress and hippocampal plasticity. Annu Rev Neurosci. 1999;22:105-122.

11. Loftis JM, Huckans M, Morasco BJ. Neuroimmune mechanisms of cytokine-induced depression: current theories and novel treatment strategies. Neurobiol Dis. 2010 Mar;37(3):519-533.

12. Miller AH, Maletic $\mathrm{V}$, Raison CL. Inflammation and its discontents: the role of cytokines in the pathophysiology of major depression. Biol Psychiatry. 2009 Mai 1;65(9):732-741.

13. Musazzi L, Treccani G, Popoli M. Glutamate hypothesis of depression and its consequences for antidepressant treatments. Expert Rev Neurother. 2012 Urr;12(10):1169-1172.

14. Yüksel C, Öngür D. Magnetic resonance spectroscopy studies of glutamate-related abnormalities in mood disorders. Biol Psychiatry. 2010 Aza 1;68(9):785-794.

15. Haroon E, Fleischer CC, Felger JC, Chen X, Woolwine BJ, Patel T, Hu XP, Miller AH. Conceptual convergence: increased inflammation is associated with increased basal ganglia glutamate in patients with major depression. Version 2. Mol Psychiatry. 2016 Urr;21(10):1351-1357. 
16. Chockalingam R, Gott BM, Conway CR. Tricyclic Antidepressants and Monoamine Oxidase Inhibitors: Are They Too Old for a New Look? Handb Exp Pharmacol. 2019;250:37-48.

17. Youdim MB, Edmondson D, Tipton KF. The therapeutic potential of monoamine oxidase inhibitors. Nat Rev Neurosci. 2006 Api;7(4):295-309.

18. Thase ME, Trivedi MH, Rush AJ. MAOls in the contemporary treatment of depression. Neuropsychopharmacology. 1995 Mai;12(3):185-219.

19. Gillman PK. Tricyclic antidepressant pharmacology and therapeutic drug interactions updated. $\mathrm{Br}$ J Pharmacol. 2007 Uzt;151(6):737-748.

20. Lochmann D, Richardson T. Selective Serotonin Reuptake Inhibitors. Handb Exp Pharmacol. 2019;250:135-144.

21. Page ME. The promises and pitfalls of reboxetine. CNS Drug Rev. 2003 Winter;9(4):327-342.

22. Machado M, Einarson TR. Comparison of SSRIs and SNRIs in major depressive disorder: a metaanalysis of head-to-head randomized clinical trials. J Clin Pharm Ther. 2010 Api;35(2):177-188.

23. Cuomo A, Ballerini A, Bruni AC, Decina P, Di Sciascio G, Fiorentini A, Scaglione F, Vampini C, Fagiolini A. Clinical guidance for the use of trazodone in major depressive disorder and concomitant conditions: pharmacology and clinical practice. Riv Psichiatr. 2019 Uzt;54(4):137149.

24. Anttila SA, Leinonen EV. A review of the pharmacological and clinical profile of mirtazapine. CNS Drug Rev. 2001;7(3):249-264.

25. Calabrese F, Molteni R, Gabriel C, Mocaer E, Racagni G, Riva MA. Modulation of neuroplastic molecules in selected brain regions after chronic administration of the novel antidepressant agomelatine. Psychopharmacology (Berl). 2011 Mai;215(2):267-275.

26. Cipriani A, Furukawa TA, Salanti G, Chaimani A, Atkinson LZ, Ogawa Y, Leucht S, Ruhe HG, Turner EH, Higgins JPT, Egger M, Takeshima N, Hayasaka Y, Imai H, Shinohara K, Tajika A, loannidis JPA, Geddes JR. Comparative efficacy and acceptability of 21 antidepressant drugs for the acute treatment of adults with major depressive disorder: a systematic review and network metaanalysis. Lancet. 2018 Api 7;391(10128):1357-1366.

27. Alamo C, García-Garcia P, Lopez-Muñoz F, Zaragozá C. Tianeptine, an atypical pharmacological approach to depression. Rev Psiquiatr Salud Ment. 2019 Uzt;12(3):170-186.

28. Woo YS, Bahk WM, Jeong JH, Lee SH, Sung HM, Pae CU, Koo BH, Kim W. Tianeptine combination for partial or non-response to selective serotonin re-uptake inhibitor monotherapy. Psychiatry Clin Neurosci. 2013 Mai;67(4):219-227.

29. Sanchez C, Asin KE, Artigas F. Vortioxetine, a novel antidepressant with multimodal activity: review of preclinical and clinical data. Pharmacol Ther. 2015 Urt;145:43-57.

30. Baldwin DS, Hansen T, Florea I. Vortioxetine (Lu AA21004) in the long-term open-label treatment of major depressive disorder. Curr Med Res Opin. 2012 Urr;28(10):1717-1724.

31. Koesters M, Ostuzzi G, Guaiana G, Breilmann J, Barbui C. Vortioxetine for depression in adults. Cochrane Database Syst Rev. 2017 Uzt 5;7(7):CD011520.

32. Borrega L, Saumell M, Isasti A, Aretxabala X, Gonzalez-Burguera I, López de Jesús M, García del Caño G, Sallés J, Barrondo S. Ketaminaren eragin antidepresiboak. Ekintza mekanismo berriak farmako antidepresiboen bilaketarako. Ekaia. 2019;35:41-56.

33. Berman RM, Cappiello A, Anand A, Oren DA, Heninger GR, Charney DS, Krystal JH. Antidepressant effects of ketamine in depressed patients. Biol Psychiatry. 2000 Ots 15;47(4):351-354.

34. Molero P, Ramos-Quiroga JA, Martin-Santos R, Calvo-Sánchez E, Gutiérrez-Rojas L, Meana Antidepressant Efficacy and Tolerability of Ketamine and Esketamine: A Critical Review. CNS Drugs. 2018 Mai;32(5):411-420.

35. Muller J, Pentyala S, Dilger J, Pentyala S. Ketamine enantiomers in the rapid and sustained antidepressant effects. Ther Adv Psychopharmacol. 2016 Eka;6(3):185-192.

36. Canuso CM, Singh JB, Fedgchin M, Alphs L, Lane R, Lim P, Pinter C, Hough D, Sanacora G, Manji H, Drevets WC. Efficacy and Safety of Intranasal Esketamine for the Rapid Reduction of Symptoms of Depression and Suicidality in Patients at Imminent Risk for Suicide: Results of a Double-Blind, Randomized, Placebo-Controlled Study. Focus (Am Psychiatr Publ). 2019 Urt;17(1):55-65. 
37. Yang C, Shirayama Y, Zhang JC, Ren Q, Yao W, Ma M, Dong C, Hashimoto K. R-ketamine: a rapidonset and sustained antidepressant without psychotomimetic side effects. Transl Psychiatry. 2015 Ira 1;5(9):e632.

38. Chi T, Gold JA. A review of emerging therapeutic potential of psychedelic drugs in the treatment of psychiatric illnesses. J Neurol Sci. 2020 Api 15;411:116715.

39. Griffiths R, Richards W, Johnson M, McCann U, Jesse R. Mystical-type experiences occasioned by psilocybin mediate the attribution of personal meaning and spiritual significance 14 months later. J Psychopharmacol. 2008 Abu;22(6):621-632.

40. Barrett FS, Doss MK, Sepeda ND, Pekar JJ, Griffiths RR. Emotions and brain function are altered up to one month after a single high dose of psilocybin. Sci Rep. 2020 Ots 10;10(1):2214.

41. Madsen MK, Fisher PM, Stenbæk DS, Kristiansen S, Burmester D, Lehel S, Páleníček T, Kuchař M, Svarer C, Ozenne B, Knudsen GM. A single psilocybin dose is associated with long-term increased mindfulness, preceded by a proportional change in neocortical 5-HT2A receptor binding. Eur Neuropsychopharmacol. 2020 Api;33:71-80.

42. Goldberg SB, Pace BT, Nicholas CR, Raison CL, Hutson PR. The experimental effects of psilocybin on symptoms of anxiety and depression: A meta-analysis. Psychiatry Res. 2020 Ots;284:112749.

43. Johnson M, Richards W, Griffiths R. Human hallucinogen research: guidelines for safety. J Psychopharmacol. 2008 Abu;22(6):603-620.

44. Carhart-Harris RL, Bolstridge M, Day CMJ, Rucker J, Watts R, Erritzoe DE, Kaelen M, Giribaldi B, Bloomfield M, Pilling S, Rickard JA, Forbes B, Feilding A, Taylor D, Curran HV, Nutt DJ. Psilocybin with psychological support for treatment-resistant depression: six-month follow-up. Psychopharmacology (Berl). 2018 Ots;235(2):399-408.

45. González-Maeso J, Weisstaub NV, Zhou M, Chan P, Ivic L, Ang R, Lira A, Bradley-Moore M, Ge Y, Zhou Q, Sealfon SC, Gingrich JA. Hallucinogens recruit specific cortical 5-HT(2A) receptormediated signaling pathways to affect behavior. Neuron. 2007 Ots 1;53(3):439-452.

46. Vollenweider FX, Vollenweider-Scherpenhuyzen MF, Bäbler A, Vogel H, Hell D. Psilocybin induces schizophrenia-like psychosis in humans via a serotonin-2 agonist action. Neuroreport. 1998 Abe 1;9(17):3897-3902.

47. Halberstadt AL, Koedood L, Powell SB, Geyer MA. Differential contributions of serotonin receptors to the behavioral effects of indoleamine hallucinogens in mice. J Psychopharmacol. 2011 Aza;25(11):1548-1561.

48. Mertens LJ, Wall MB, Roseman L, Demetriou L, Nutt DJ, Carhart-Harris RL. Therapeutic mechanisms of psilocybin: Changes in amygdala and prefrontal functional connectivity during emotional processing after psilocybin for treatment-resistant depression. J Psychopharmacol. 2020 Ots;34(2):167-180.

49. Dos Santos RG, Hallak JEC. Therapeutic use of serotoninergic hallucinogens: A review of the evidence and of the biological and psychological mechanisms. Neurosci Biobehav Rev. 2020 Urt;108:423-434.

50. Palhano-Fontes F, Barreto D, Onias H, Andrade KC, Novaes MM, Pessoa JA, Mota-Rolim SA, Osório FL, Sanches R, Dos Santos RG, Tófoli LF, de Oliveira Silveira G, Yonamine M, Riba J, Santos FR, Silva-Junior AA, Alchieri JC, Galvão-Coelho NL, Lobão-Soares B, Hallak JEC, Arcoverde E, Maiade-Oliveira JP, Araújo DB. Rapid antidepressant effects of the psychedelic ayahuasca in treatment-resistant depression: a randomized placebo-controlled trial. Psychol Med. 2019 Mar;49(4):655-663. 